Department of Food Hygiene,

Animals Health Institute, Alexandria.

\title{
EFFECT OF BOILING AND FREEZING ON CIPROFLOXACIN RESIDUES IN CHICKEN TISSUES (With 2 Tables)
}

\author{
By \\ MONA O. ABOUL EL-NILE \\ (Received at 17/6/2006)
}

تأثير الغليان والتجمبي على بقايا السبروفتوكساسين فى أنسجة الاجاج

$$
\text { هنى عدر أبو النتيل }
$$

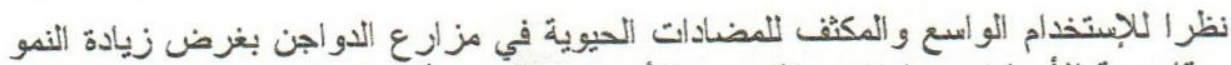

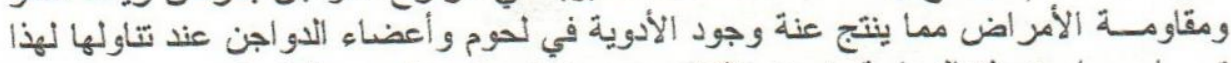

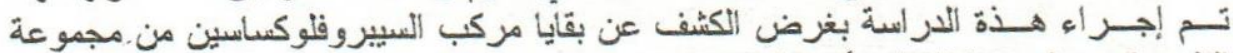

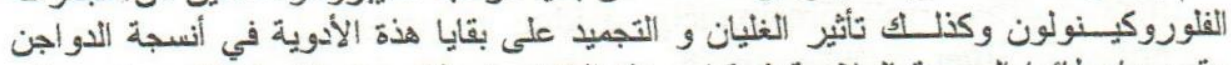

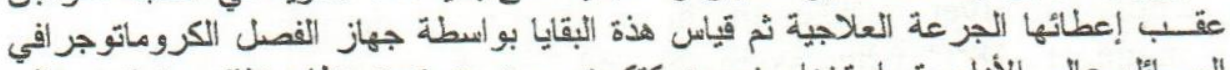

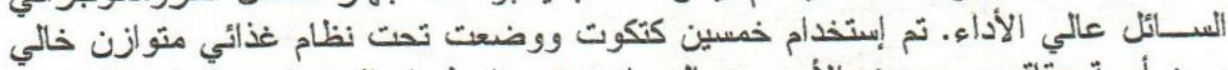

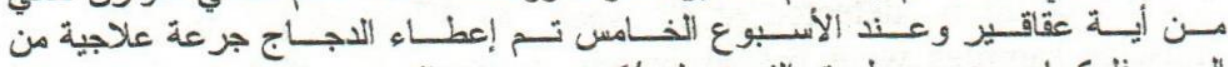

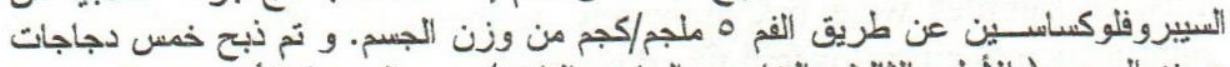

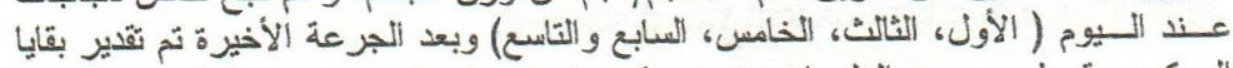

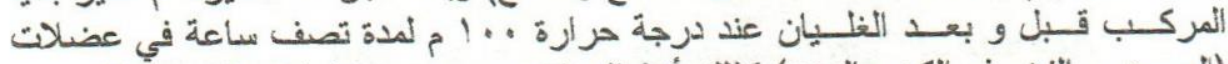

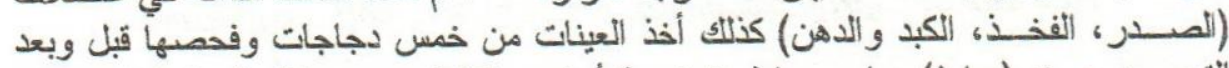

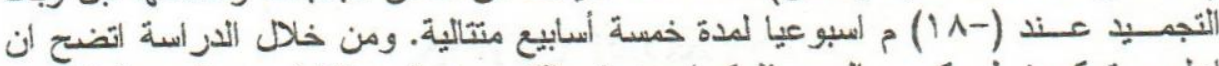

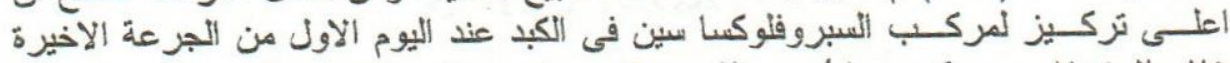

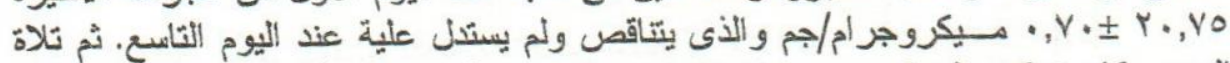

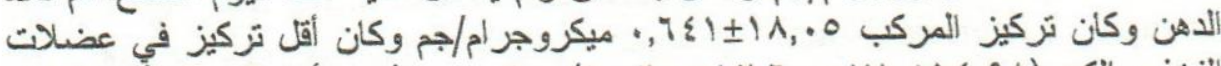

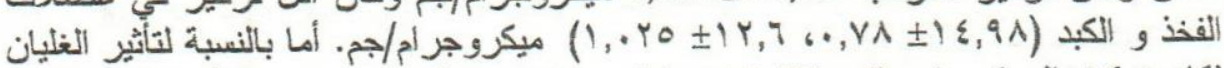

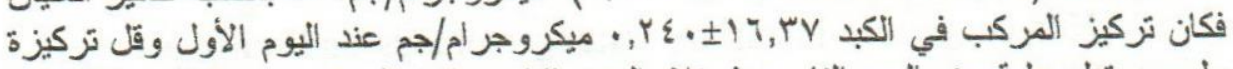

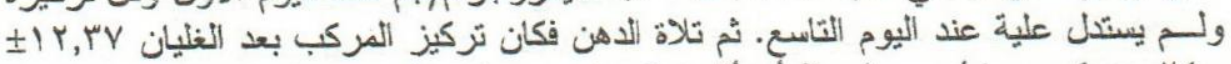

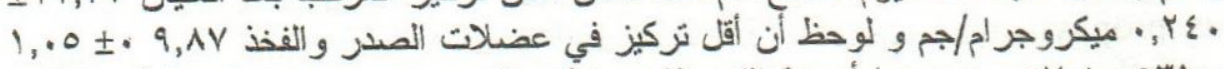

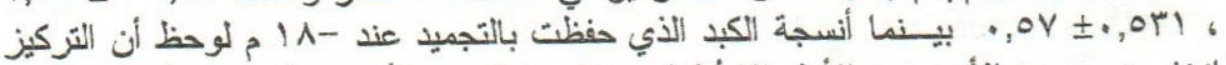

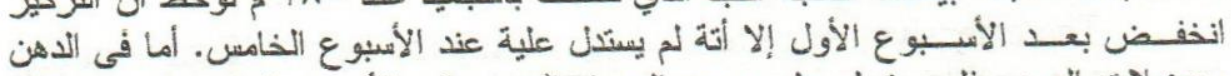

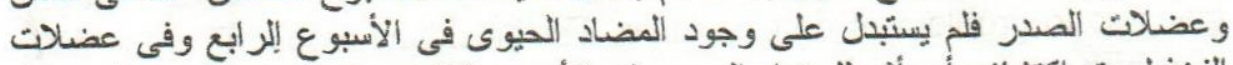

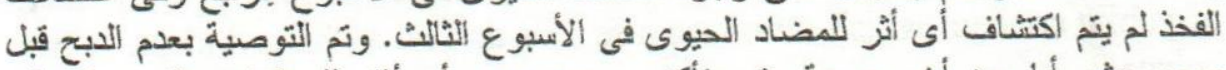

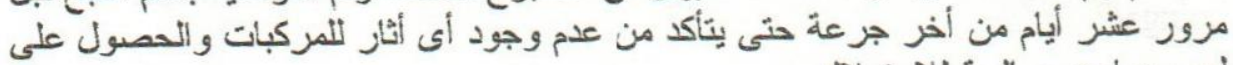

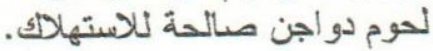




\section{مزور عشر أيام من أخر جزعة حتى يتأكد من عدم وجود أى أثناز للمزكبات والحصول على لحوم دواجن صالحة للاسنهلاكي.}

\section{SUMMARY}

Fifty apparently healthy one day old chicks were given orally ciprofloxacin $5 \mathrm{mg} / \mathrm{kg}$ b.wt for 5 successive days. Groups of 5 broilers were slaughtered at $1^{\text {st }}, 3^{\text {rd }}, 5^{\text {th }}, 7^{\text {th }}$ and $9^{\text {th }}$ day after administration of the last dose. Muscles (breast and thigh), liver and fat of each broiler group were examined now and after boiling at $100^{\circ} \mathrm{C}$ for 30 minutes using for determination of ciprofloxacin residue and its, persistence at high temperature. Raw breast, liver and fat samples showed gradual decrease of ciprofloxacin residue whereas a marked decrease was observed in heat treated samples where at $9^{\text {th }}$ day both raw and boiled samples were negative for the drug. Thigh muscles samples proved to be free from any drug residue at $5^{\text {th }}$ day while both raw and boiled samples were free at $7^{\text {th }}$ dose storage. On the other hand, frozen storage $\left(-18^{\circ} \mathrm{C}\right)$, broiler, had a marked effect on ciprofloxacin residue in breast, thigh, liver and fat samples. In liver samples the drug failed to be detected at $5^{\text {th }}$ week of storage at $-18^{\circ} \mathrm{C}$ whereas in fat and breast muscle samples, no drug residue could be detected at $4^{\text {th }}$ week. At $3^{\text {rd }}$ week of storage, thigh muscles samples were free from any drug residue. The public health significance of ciprofloxacin was discussed.

Key words: Ciprofloxacin, residues, chicken, boiling, freezing.

\section{INTRODUCTION}

Ciprofloxacin is a new fluoroquinolone antimicrobial agent, with a rapid bactericidal activity against a broad spectrum of bacteria (Sanders et al., 1987).

Nowadays, the intensive farming methods and mass production of poultry are developing more and more, thus the use of antimicrobial as prophylactic means to prevent and control infection and promote growth is increasing rapidly.

The extensive use of these drugs during the whole life time of bird give rise to problem of drug residues. The "residues problem" is the focus of public concern which introduce a serious and novel hazard to the human beings. 
These residues comprise the non-altered parent compound as well as metabolites and or conjugates (Haagsma, 1993).

The present study was conducted to detect the possibie residues of ciprofloxacin in chicken tissues and the effect of heating and freezing storage on ciprofloxacin residues.

\section{MATERIALS and METHODS}

\section{Materials}

\section{1-Drug}

\section{Ciprofloxacin (ciprotril) ${ }^{\circledR}$}

Ciprofloxacin is a fluroquinolone antibacterial agent with a wide spectrum of activity.
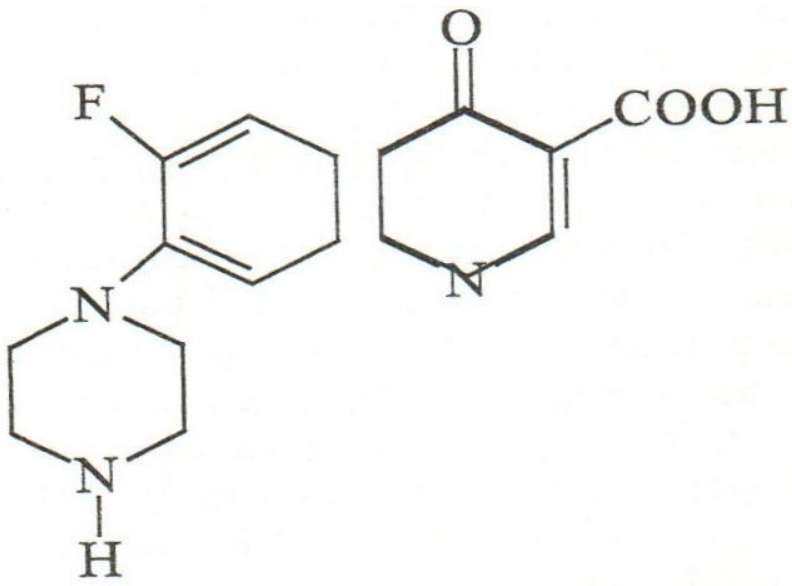

Structural formula of ciprofloxacin (Lebel, 1988)

\section{Chemical formula $\mathrm{C}_{17} \mathrm{H}_{18} \mathrm{FN}_{3} \mathrm{O}_{3}$ :}

Chemical name: (1-Cyclopropyl-6-fluoro-1,4-dihydro 4-oxo-7piperazin-1-ylguino line-3-carboxylic acid).

Dose for poultry is $100 \mathrm{ml} / 200$ litre of drinking water ( $5 \mathrm{mg} / \mathrm{kg}$ bwt) for 5 days.

\section{2- Experimental chicks:}

Fifty apparently healthy, one day old chicks were obtained from El-Salam farm in $10^{\text {th }} \mathrm{f}$ Ramadan city. They were fed on a balanced commercial ration free from any medication and water was provided adlibitum. All hygienic measures were adopted as recommended. Temperature was adjusted according to age (Start at $32^{\circ} \mathrm{C}$ and decreased $2{ }^{\circ} \mathrm{C}$ each week). 


\section{Methods}

1- All chicks were vaccinated against Newcastle disease on $6^{\text {th }}$ day of age and against Gumboro disease on $15^{\text {th }}$ day of age.

2- At the $5^{\text {th }}$ week chicks were treated with ciprofloxacin $(5 \mathrm{mg} / \mathrm{kg}$ body wt) for five successive days for detection of drug residues.

3 - five broiler were slaughtered on $1^{\text {st }}, 3^{\text {rd }}, 5^{\text {th }}, 7^{\text {th }}$ and $.9^{\text {th }}$ day after the last dose.

Muscles (breast, thigh) fat and liver samples were examined before and after boiling $\left(100^{\circ} \mathrm{C}\right.$ for 30 minutes) for detection of ciprofloxacin residues and studying effect of heating on its persistence.

4- Samples from breast, thigh, fat and liver were examined before freezing and kept at $-18^{\circ} \mathrm{C}$ then examined weekly for presence of ciprofloxacin residues. The time elapsed from the onset of freezing till complete disappearance of the residues was recorded.

Detection of ciprofloxacin residues: Ciprofloxacin residues were determined using high performance liquid chromatography (HPLC) Knoure, Inc Germany, according to the method described by Groeneveld and Brouwers (1986). Ciprofloxacin was extracted from samples with dichloromethane and $0.1 \mathrm{M}$ sodium phosphate buffer at $\mathrm{pH} 7.4$ chromatography was performed on an amino-exchange column with the mobile phase and tested using UV defector, UV absorbance and monitored at $278 \mathrm{~nm}$. In to a $10 \mathrm{ml}$ extraction tube of $1 \mathrm{gm}$ of homogenized tissue (breast, thigh, fat and liver) and $1 \mathrm{ml}$ of $0.1 \mathrm{M}$. Phosphate buffer $\mathrm{pH} 7.4$ were added. After adding $5 \mathrm{ml}$ dichloromethane, the tube was stoppered and gently shaked at 100 cycle/min for 10 minutes and centrifuged at $4000 \mathrm{rpm}$ for $10 \mathrm{~min}$ at room temperature.

After removing the aqueous layer, the organic layer was transferred into another tube and dried under nitrogen at $50^{\circ} \mathrm{C}$.

The residues were dissolved in $1 \mathrm{ml}$ mobile phase using a vortex mixer and sonication, before HPLC analysis depending on concentration, 5-20 $\mathrm{ml}$ was infected.

\section{Standard preparation}

Ciprofloxacin standard solution was prepared from (100\%) drug pure by dissolving a weighed amount of drug in distilled water to make stock solution.

\section{Statistical analysis}

It was carried out according to Snedecor and Cochran (1967). 
Assiut Vet. Med. J. Vol. 52 No. 110 July 2006

RESULTS

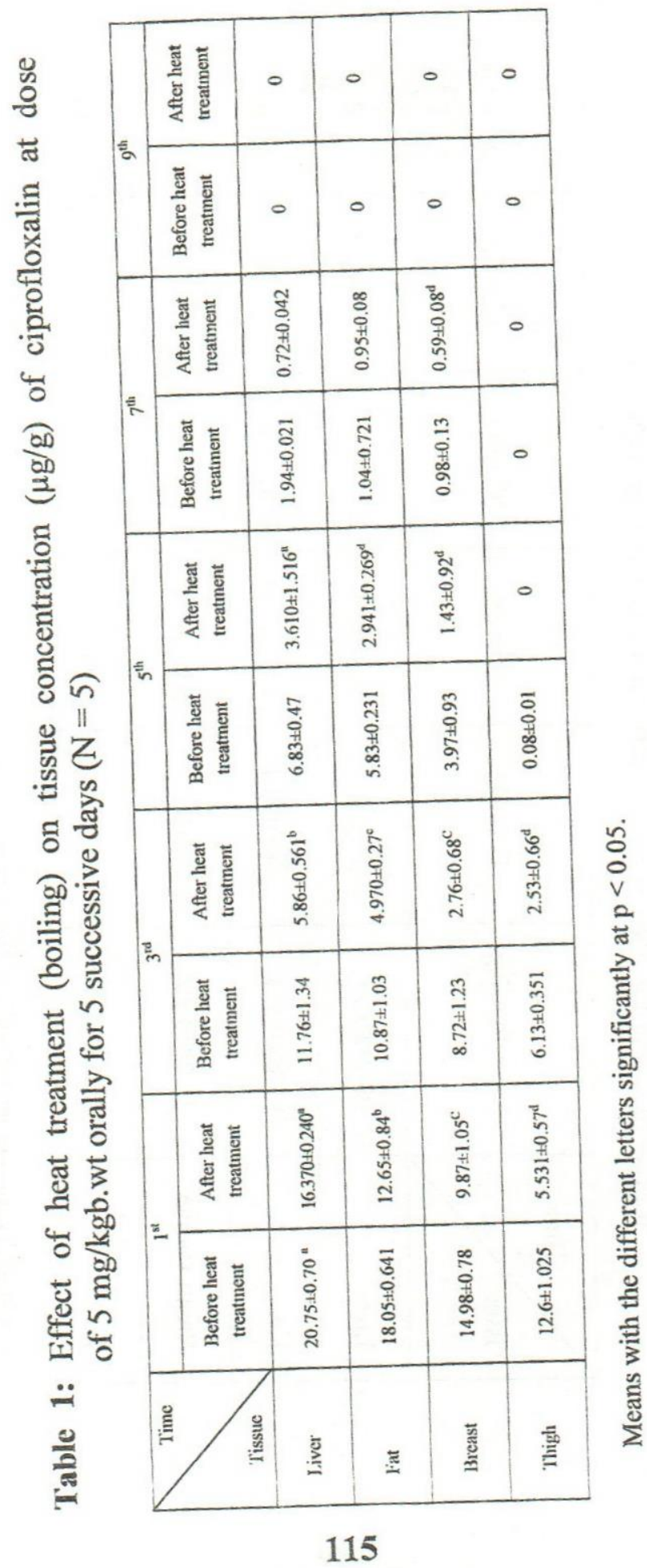


Assiut Vet. Med. J. Vol. 52 No. 110 July 2006

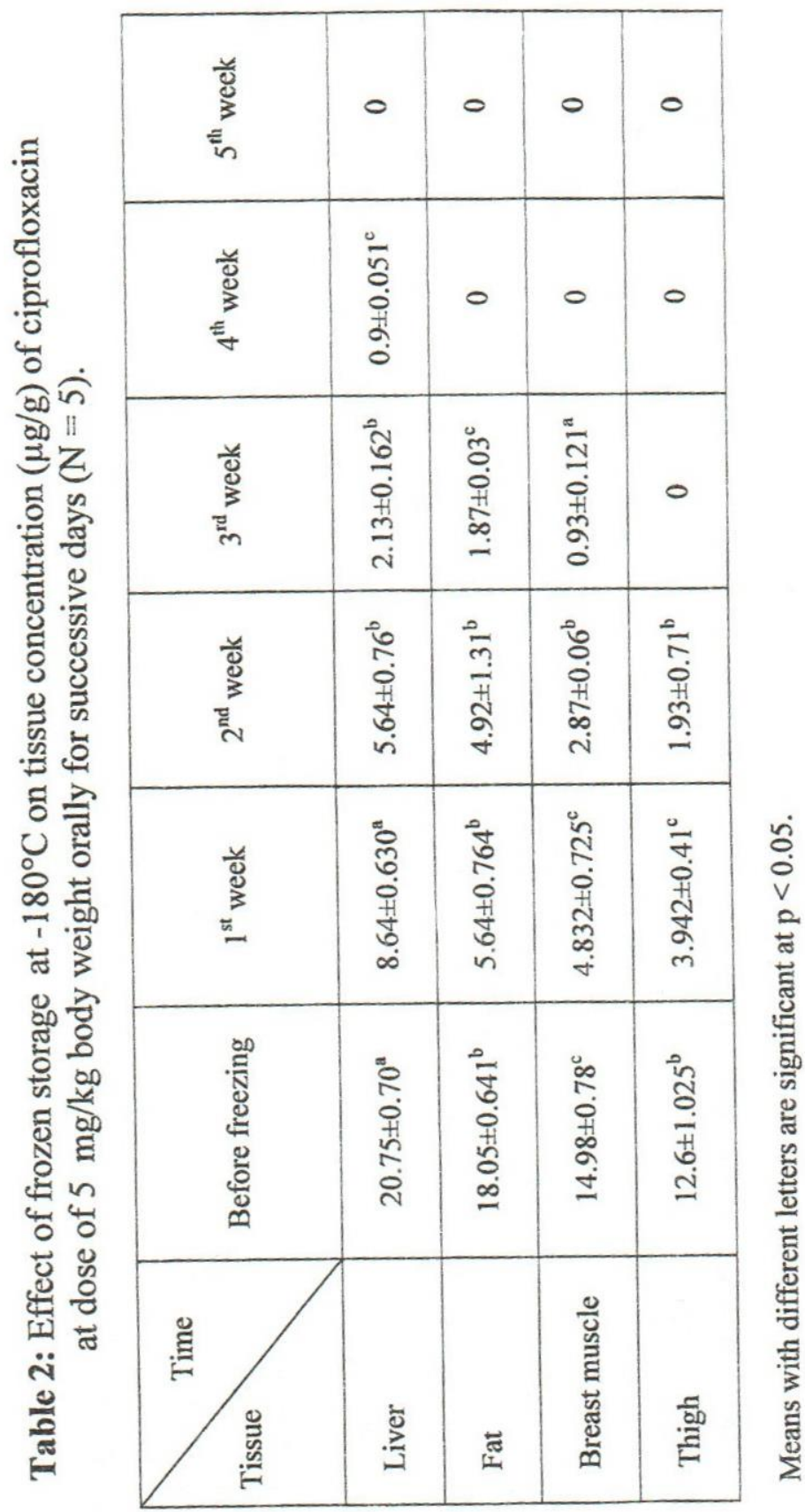




\section{DISCUSSION}

Residues of veterinary medicinal products as defined by European union, are pharmacologically active substance (whether active principles, excipients or degradation products) and their metabolites which remain in food stuffs obtained from animals to which the veterinary medicinal product in question has been administered (Van dercreek, 1984).

The potential problem associated with drug residues may be classed in two broad categories. First, aesthetics, consumers call of us don't like the idea of foreign substance being present in food. The second problem is that of potential health risks. There potential health problems include allergic reactions, direct toxic effects and a change in the resistance patterns of bacteria exposed to antibiotics (Weaver., 1992)

In the present study, ciprofloxacin administration orally to chicken at dose of $5 \mathrm{mg} / \mathrm{kg}$ b.wt for five successive days (Table 1) revealed that the mean highest concentration level of ciprofloxacin was detected in fiver at $1^{\text {st }}$ day from administration of last dose $(20.75 \pm 0.703$ $\mathrm{ug} / \mathrm{g})$ and its level showed significant decrease $(\mathrm{p}<0.05)$ in the $3^{\text {td }}, 5^{\text {th }}$, $7^{\text {th }}$, day $(11.76 \pm 1.34,6.83 \pm 0.047,1.94 \pm 0.021$ respectively) until not detected at $9^{\text {th }}$ day. The effect of heat treatment (Boiling at $100^{\circ} \mathrm{C}$ for 30 minutes) showed significant decrease $(16.370 \pm 0.24 \mathrm{ug} / \mathrm{g})$ at $1^{\text {st }}$ day and its level decreased significantly (at $p<0.05)$ in $3^{\text {rd }}, 5^{\text {th }}, 7^{\text {th }}(5.86 \pm 0.561$, $3.610 \pm 1.516,0.72 \pm .042 \mathrm{ug} / \mathrm{g}$ respectively) till not detected at $9^{\text {th }}$ day.

The drug concentration level in liver was followed by fat that concentration $(18.05 \pm 0.641 \mathrm{ug} / \mathrm{g})$ and its level decreased till not detected at $9^{\text {th }}$ day $(10.87 \pm 1.03,5.83 \pm 0.231,1.04 \pm 0.72 \mathrm{ug} / \mathrm{g})$. The effect of boiling showed a significant decreased till not detected at $9^{\text {th }}$ day $(12.65 \pm 0.84,4.970 \pm 0.27,2.941 \pm 0.269,0.95 \pm 0.08 \mathrm{ug} / \mathrm{g})$.

Breast muscle concentration level before heat treatment was $14.98 \pm 0.78 \mathrm{ug} / \mathrm{g}$ which decreased till not detected at $9^{\text {th }}$ day $(8.72 \pm 1.23$, $3.97 \pm 0.93,0.98 \pm 0.13 \mathrm{ug} / \mathrm{g})$. The effect of boiling showed significant decreased till not detected at $9^{\text {th }}$ day $(9.87 \pm 1.05,2.76 \pm 0.68,1.43 \pm 0.92$, $0.59 \pm 0.08 \mathrm{ug} / \mathrm{g})$, respectively. Lowest ciprofloxacin concentration was detected in thigh muscle $12.6 \pm 1.025 \mathrm{ug} / \mathrm{g}$ ) and decreased till not detected at $5^{\text {th }}$ day from drug administration, $(6.13 \pm 0.351,0.08 \pm 0.01 \mathrm{ug} / \mathrm{g})$. After heat treatment low concentration (5.531 to 0.57 and $2.53 \pm 0.061$ ) of ciprofloxacin could be detected in thigh muscle during $1^{\text {st }}$ and $3^{\text {rd }}$ day and failed to be detected at $5^{\text {th }}$ day. 
Forzen storage $\left(-18^{\circ} \mathrm{C}\right)$ of liver resulted in gradual decrease in the concentration of ciprofloxacin $(8.64 \pm 63,5.64 \pm 0.76,2.13 \pm 0.16$ and $0.9+0.051 \mathrm{mg} / \mathrm{g}$., receptively) from the $1^{\text {st }}$ till the $4^{\text {th }}$ week of storage until not detected in the $5^{\text {th }}$ week. The same manner was observed for (5.64 $\pm 0.76,4.29 \pm 1.31$ and $1.87 \pm 0.03 \mu / \mathrm{g}$, respectively) and breast muscles $(4.83 \pm 0.72,2.87 \pm 0.06$ and $0.93 \pm 0.12 \mu \mathrm{g} / \mathrm{g}$ respectively) but at $4^{\text {th }}$ week of storage the drug failed to be detected. As for thigh muscle samples, ciprofloxacin could not be recovered at $3^{\text {rd }}$ week of storage as presented in Table (2).

Our results are in agreement with Elin (1999) who found that the highest concentrations level was in liver followed by fat and muscles where the residues disappeared at $10^{\text {th }}$ day of administration of the last dose. Elinstein et al., (1994) reported that all flouroquinolones are well absorbed after oral administration were flouroquinolones (FQS) are minimally protein bound and widely distributed in body tissue.

Anadon et al., (1985) found that when norfloxacin was administrated orally the concentration in breast, fat and liver was 0.05 $\mathrm{ug} / \mathrm{g}$ on the second day after the end of dosing. Bergeron et al., (1985) reported that the concentration of norfloxacin in kidney parenchyma was 4-12 times of the serum concentration.

Scheer (1987) reported that intravenous injection of baytril showed highest concentration in liver, kidney. Alesling (1990) found that the highest concentration were in liver and breast muscle.

Available literature are lacking any figures concerning the effect of boiling and freezing of ciprafloxalin is fluoroquinolonas are similar to antibiotics in their distribution and activity.

Scheibner (1969) stated the heating of meat at $60^{\circ} \mathrm{C}$ for 60 minutes had no effect on antibiotic residues, but heating to $90^{\circ} \mathrm{C}$ minimized to some extent the antibiotic activity. The antibiotic residues completely disappeared immediately if the meat was cooked at cooking temperature for 20 minutes. Chunba (1972) showed that normal methods of cooking destroyed aureomycin and terromycin Katz et al. (1972) reported that cooking of broiler tissue and organs containing chlorotetracycline residues converted the residues to isochlorotetracycline which had no known biological activity.

Vandenbrande et al. (1972) stated that cold storage of meat reduced the activity of penicillin residue. Hassan (1995) reported that the oral administration of tylosine $25 \mathrm{mg} / \mathrm{kg}$ b.wt. twice daily for 5 successive days and boiling of chicken tissues and organs for 30 minutes completely degraded tylosene residues in all tissue samples and at $5^{\text {th }}$ week of 
freezing tylosine residues were completely disappeared from liver, fat and breast.

Haagsma (1993) stated that the content of residues of many veterinary drugs decreased not only as a result of food preparing and processing, but also at cooled and frozen storage.

Amer et al. (1994) concluded that gentamicine at dose of $6 \mathrm{mg} / \mathrm{kg} \mathrm{b.wt}$. intramuscularly daily for 7 successive days disappeared by boiling the muscle samples for 45 minutes and freezing for one week.

Gyhan (1997) found that apramycin sulphate residues in chicken tissues after boiling at $100^{\circ} \mathrm{C}$ for $45^{\circ}$ mintues failed to be detected in liver, kidney, gizzard and fat after 48 hours from the last oral dose and the residues disappeared from breast and thigh muscles, liver, kidney, gizzard and fat after the third week from freezing and disappeared from skin after 2 day from freezing samples.

Pouliques and Morvan (2002) determined the residues of oxolinic acid $(\mathrm{OA})$ and flumequine in freeze-dried salmon muscle with attached skin, using reversed-phase (HP/C). They concluded that the limits of detection were 3.2 and $16 \mu \mathrm{g} / \mathrm{g}$.

From this study one can conclude that broilers must be slaughtered 10 days after the last dose of treatment to protect the consumer from the public health hazards of antibiotics.

\section{REFERENCES}

Alestig, K. (1990): Pharmacokinetics of oral quinalones (norfloxacin, ciprofloxacin, ofloxacin). Scand. J. Infect. Dis. (supp. 86: 12-22).

Amer, M.S.; Waffia, H.; Abde-Alla, Koshaik M.Y.; Abdel Aleam, A.F. and Gamma, H.A. (1994): Gentamicine and netilmicin residues in tissues and organs of treated rabbits. Vet. Med. J. of Giza; 42: 95-9.

Anadon, A.; Morting, M.R.; Diaz, M.J.; Fernandez, R. and Fernandez, M.C. (1995): Pharmacokinetics and tissue residues of nor floxacin and its N.desenthyl and oxometabolites in chicken. Journal of Veterinary Pharmacology and Therapeutics; 18(3): 220-5.

Bergeron, M.G.; Thabet, M.; Ray, R. and Pessard, C. (1985): Norfloxacin penetration into human renal and prostatic tissue. Antimicob. Agents Chemother. 28: 349-350.

Chunha, J.J. (1972): Hormones and feed additives use and control proceeding of meat. Industry research conference; Mar. 1. 
Eïstein, M.E.; Malom, 2.I. and Acar, J.F. (1994): Introduction of fluoroquinolones in veterinary medicine. J. Antimicrob. Chemother. 13-102-122.

Elin. E.E. Mankorios (1999): some pharmacological studies on ciprofloxacin in chicken. Thesis presented by faculty of Vet. Med. Zagazing Univ. for degree of PHD (pharmacology).

Groeneveld, A.J.W. and Brouwer, SJ. R.B.J (1986): Quantitative determination of alfloxacin, ciprofloxacin, norfloxacin and pefloxacin in serum by high pressure liquid chromatography. Pharm Weckbl (Sci; 8: 79-84).

Gyhan, R.A. (1997): Habhazard uses of antibiotic in Egyptian poultry farms. Thesis for PHD Cairo University Pharmacology.

Haagsma, N. (1993): Stability of veterinary drug residue during storage. Preparation and processing of the Euro residue II conference veldhoven. The Netherlands: Vol. (1): 41-9.

Hassan, M.M.N. (1995): Some antibacterial residues in chicken meat. M.V.Sc. Thesis Cairo University (pharmacology).

Katz, S.E.; Fassbender, G.A. and Porfman, D. (1972): Chlortetracycline residues in broilers tissue and organs. J A.O.A.C; 55: 134.

Lebel, M. (1988): Ciprofloxacin chemistry, mechanism of action, resistance antimicrobial spectrum, pharmacokinetics, clinical trails and adverse reactions. Pharmacology 8: 3-33.

Pauliques, H. and Morvan, M.L. (2002): Determination of oxolinic acid and flumequine in freeze dried salmon muscle and skin by HPLC with fluorescence detection. Food Addit Contam 19(3): 233-31.

Sanders, C.C.; Sanders, W.E. and Goering, R.V. (1987): Overview of preclinical studies with ciprofloxacin. Am. J. Med., 82: 2-11.

Scheer, M. (1987): Studies on the antibacterial activity of Bytril. Vet. Med. Review; 2: 90-9.

Scheibner, V.G. (1969): Occurrence and decomposition of antibiotic in meat. Monatschreft furvetarinar median Heft, 24: 39.

Snedecor, G.W. and Cochran, W.G. (1967): Statistical Method $6^{\text {th }}$ ed. Iowa stage Univ. Press Ames, Iowa, U.S.A.

Van dercreek, F.W. (1984): Veterinary drug residues in food. Tijdschr. Diergeneeskd. 1; 109 (3): 81-89.

Vandenbrande, G.; Hoof Van, J. and Dedken, F. (1972): Use of sarcina lutea ATCC 9341 to detect microbiologically active residues in the meat of cattle. Vlaams Diergenesskunding. Tijdschrift 41 (718): 333 .

Weaver, L.D. (1992): Antibiotic residues is milk and meat precipitations and realities Vet. Med. 87: 1222-1228. 